\title{
The effect of fermentation on functional properties of sweet potato and wheat flour
}

\author{
Adams Oluwadamilola Kemi ${ }^{1}$, Adams Ifeoluwa Mercy ${ }^{2}$, Orungbemi $\mathrm{OO}^{3}$ \\ ${ }^{1}$ National Defense College Abuja \\ ${ }^{2}$ University of Ilorin Kwara State \\ ${ }^{3}$ Rufus Giwa Polytechnic Owo Ondo State \\ Corresponding Author's Email:lizbethdammy@yahoo.com
}

\begin{abstract}
In this study, the functional properties of flour produced from wheat flour and blended with unfermented and fermented sweet potato flour in the following ratios (WF:USPF:FSPF:100:0:0,0:100:0,$0: 0: 100,90: 10: 0,90: 0: 10)$ were evaluated. The result obtained showed that fermentation improved the foaming capacity, $(2.00 \%$ to $8.00 \%)$, emulsion capacity $(23.66 \%$ to $25.72 \%)$ and least gelation $(6.00 \%$ to $10.00 \%) .100 \%$ USPF with the highest bulk density of $2.50 \mathrm{~g} / \mathrm{cm}^{3}$ and the highest oil absorption capacity of $220.00 \%$ while $90 \%$ WF:10\% FSPF with the highest water absorption capacity of $200.00 \%$ had the highest swelling capacity of 0.80 . The results show that blending wheat flour with fermented sweet potato flour improves the functional properties.
\end{abstract}

Keywords: Fermentation, Functional Properties, Sweet Potato Flour

\section{INTRODUCTION}

Sweet potato (Ipomoea batatas) is a dicotyledonous starchy, sweet tasting, tuberous roots are a root vegetable (John,1998). The young leaves and the shoots are sometimes eaten as green. Ipomoea batatas is native to the tropical regions in American (Woolfe, 1992) .

Sweet potato was also grown before western exploration in Polynesia. Sweet potato has been radio carbonated in the cook islands to $1000 \mathrm{AD}$, and current thinking is that it was brought to the central poiynesia around 700AD (Ladefoged, et al, 2005). Sweet potato flour is produced from white sweet potato and dull white in colour, stiff in texture and has a somewhat sweet flavor it is high in fibre and contain higher level of carbohydrates and a lower level of protein than common wheat flour.(Tewe, et al, 2003). Sweet potato flour can be used for baked goods such as bread, cookies, muffles, pancakes, doughnuts and has a thickner for sauces and gravies .Commonly used in gluten free cooking and baking,(Odebode, 2004). Sweet potato (Ipomoea batatas $\mathrm{L})$, is among the worlds most important, versatile, and under exploited food crops, with more than 133million tones (FAOSTAT,1997) in annual productions.

\section{Objective of the Study}

The objective of this project is to evaluate the effect of fermentation on functional properties of sweet potato flour in order to increase its usefulness.

\section{Literature review}

Origin and history of sweet potato

Sweet Potato (Ipomoea batatas (L) was originally domesticated in tropical America (Roulier, et al 2013). The exact center of origin and domestication of the sweet potato has not been well defined, neither has the wild ancestor of this species been found (Denham, 2011) Sweet potato currently ranks as the most important food crop on a fresh weight basic in developing countries after rice, wheat, maize and cassava, Among the root and tubers crops, it is the only one that has a positive per capital annual rate of increase in production in subsaharan Africa (Bashaasha and Mwanga,1996). 


\section{Nutritional composition}

Although they are soft and creamy enough to be putin pies and called desert, sweet potatoes are also a surprising nutritious vegetable.(Low JP, 1996).

Sweet potatoes are high in vitamin A, vitamin B5,B6, thiamin, niacin, riboflavin and due to their orange colour, are high in carotenoids said san Diego based nutritionist, they are fat free, relatively low in sodium and have fewer calories than white potatoes, although they have more sugar.(Tewe,2000).

\section{Health benefit of consuming sweet potatoes}

Not only are sweet potatoes readily available, inexpensive and delicious, sweet potatoes decreases the risk of obesity, diabetics, heart disease and overall mortality while promoting a health complexion increased energy and overall lower weight (Schoffro ,1998). They are many other benefits for your health.

\section{METHODOLOGY}

\section{Sources of raw material}

Wheat flour, fermented and unfermented sweet potato flour where purchased from a well known market called 'sasa market' in Akure South local government area of Ondo State.

Equipment such as blender, centrifuging machine, magnetic stirrer, graduated cylinder water bath, test tube, measuring cylinder were used when carrying out the analysis.

\section{Preparation of raw materials}

\section{Preparation of unfermented orange fleshed sweet potato flour}

The sweet potato flour was produced using the method described (Huang and sun, 2000).The orange fleshed sweet potato tuber were peeled and cut into thin pieces manually. The potato slices were then first immersed into $(1 \%)$ Nacl solution into a solution containing potassium metabisulphate $(1 \%)$ and citric acid $(0.5 \%)$ and enhance the colour of the flour. Drying of sweet potato slices was done on perforated tray in a tray dryer (Tewe, 2005) at 55 degree Celsius till constant weight. The dried sweet potato chips were milled into four using the laboratory grinder (Roullier 2013) and passed through 250ÑM mech sieve, packed in air tight container and store in the refrigerator till further use.

\section{Functional properties of sweet potato flour}

\section{Determination of bulk density}

The bulk density (BD) was determined according to the method described by Okaka and Potter (1977). A 20g sample was put into a $100 \mathrm{ml}$ graduated cylinder. The cylinder was tapped on the palm for 40 to 50 times and the bulk density was determined by reading the final volume.

Bulk density was calculated as.

$$
\mathrm{BD}=\frac{\text { Mass of Materials }}{\text { volume of Material after Tapping }}
$$

\section{Determination of foaming capacity}

The method of Coffman and Garcia (1977) was employed the determination of foaming capacity. $1 \mathrm{~g}$ sample was whipped with $50 \mathrm{ml}$ distilled water for 5 minutes in a Kenwood blender at speed set at maximum and poured into a $100 \mathrm{ml}$ graduated cylinder. Total volume at time interval at 0,5 mins, 10 mins until 1 hour was noted to study the foaming stability.

$\%$ volume increase $=\underline{\text { Vol after whipping-volume before }}$ whipping

$$
\text { Vol before whipping } \times 100
$$

\section{Determination of water and oil absorption capacity}

Water absorption capacities (WAC) of the sample were determined by a combination Salunkhe and Sathe et al, (1982). Methods $1.0 \mathrm{~g}$ sample was mixed with $10 \mathrm{ml}$ of water for 5 minutes on a magnetic stirrer or using glass rod, the mixture was centrifuged at 3,500 rpm for 30mins and the volume of the supernatant left after centrifuging was noted. Water bound was calculated from the difference in the initial volume of water used and the final volume after centrifuging.

The same procedure was used for oil absorption capacity (OAC), Just that oil was used in place of water.

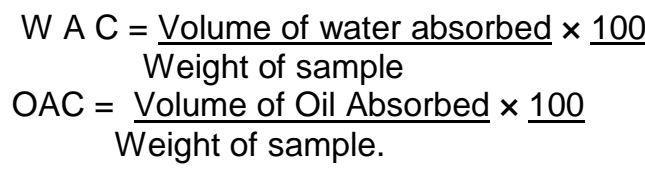

\section{Least gelation concentration (L G C)}

The least Gelation concentration ( $L G C$ ) of the flour blends will be determined using modified method of (Coffman and Garcia 1977) sample suspensions of $2 \%$, $4 \%, 6 \%, 8 \%, 10 \%, 12 \%, 14 \%, 16 \%, 18 \%$ and (M/V) will be prepared in $10 \mathrm{ml}$ distilled water in the test tube.

The tubes containing the suspension the suspensions will then be heated for 1hour in a gentle boiling water bath, after which the tubes will be cooled rapidly in water 
016 Afr. J. Food Sci. Technol.

Table 1.Nutritional composition of sweet potato flour and the amount per servings

\begin{tabular}{lll}
\hline Nutritional Facts & Amount Per Serving \%DV & Amount Per Serving \%DV \\
\hline Serving size 1 medium & Total fact 0g $0 \%$ & Total carbohydrate 23g $8 \%$ \\
Calories from fat o & Potassium 4400mg 13\% & Protein $2 \mathrm{~g}$ \\
\hline
\end{tabular}

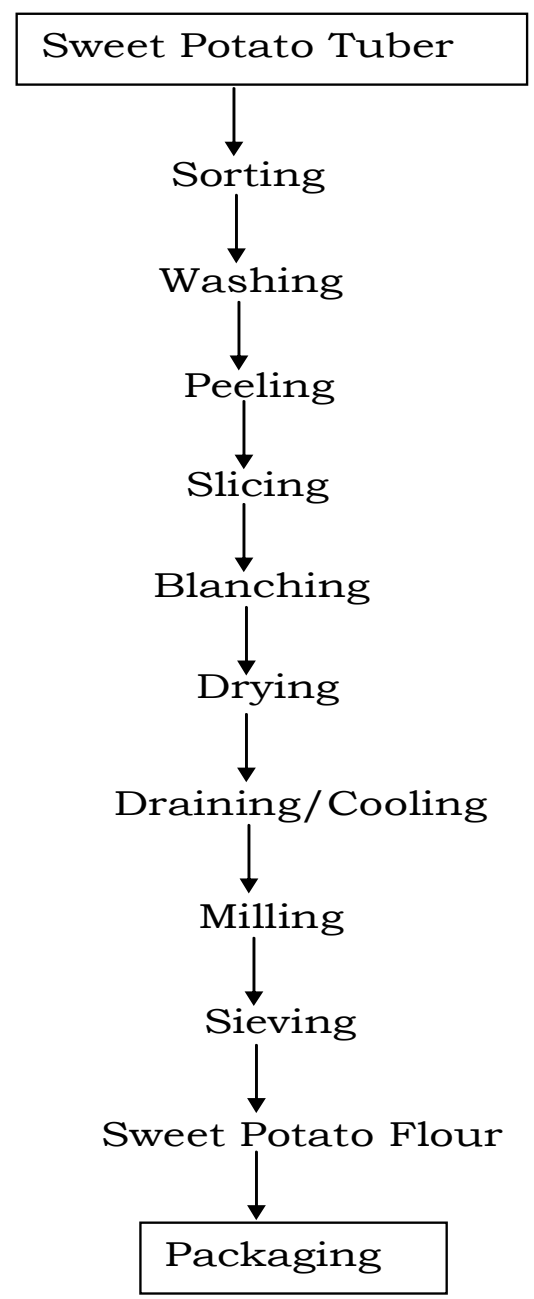

Figure 1.The flow chart for the production of unfermented sweet potato

at $40^{\circ} \mathrm{C}$ for 2 hours. Each tube will be then inveted one after the other. The L.G.C will be taken as the concentration that when the sample from the inverted test tube does not fall or sleep.

\section{Determination of swelling index}

The swelling index was determined using the method of Leach (1959). $75 \mathrm{~g}$ of each sample was weighed into a $500 \mathrm{ml}$ of water added and allowed to stand for 4 hours the level of swelling was Observed thereafter. Swelling Index = volume after soaking - volume of the sample

$$
\text { Weight of the sample }
$$

\section{Emulsion capacity determination}

The emulsion capacity (EC) was determined by the method of Beuchat (1977). The emulsion $1 \mathrm{~g}$ of sample, $10 \mathrm{ml}$ distilled water and $10 \mathrm{ml}$ of soya bean oil was 
Table 2. Functional Properties of Fermented and Unfermented Sweet Potato and their Blend with Wheat Flour

\begin{tabular}{llllll}
\hline Properties & $\mathbf{1 0 0 : 0 : 0}$ & $\mathbf{0 : 1 0 0 : 0}$ & $\mathbf{0 : 0 : 1 0 0}$ & $\mathbf{9 0 : 1 0 : 0}$ & $\mathbf{9 0 : 0 : 1 0}$ \\
\hline Bulk Density $(\mathrm{g} / \mathrm{ml})$ & 0.87 & 2.50 & 2.00 & 1.37 & 0.51 \\
Foaming Capacity & 12.00 & 2.00 & 8.00 & 4.00 & 10.00 \\
Water Absorption Capacity(\%) & 190.00 & 110.00 & 140.00 & 160.00 & 200.00 \\
Oil Absorption Capacity (\%) & 160.00 & 220.00 & 190.00 & 170.00 & 150.00 \\
Swelling Index & 0.79 & 0.74 & 0.75 & 0.77 & 0.88 \\
Least Gelation (\%) & 18.00 & 6.00 & 10.00 & 12.00 & 16.00 \\
Emulsion Capacity (\%) & 15.00 & 23.66 & 25.72 & 10.68 & 11.72 \\
\hline
\end{tabular}

prepared in a calibrated centrifuge tube. The emulsion was centrifuged at $3,500 \mathrm{rpm}$ for 5 minutes. The ratio of the height of the emulsion layer to the height of the emulsion layer to the height of the mixture was calculated as the emulsion activity expressed in percentage.

Formula for the emulsion capacity

$\mathrm{EC}=$ The ratio of height of emulsion layer

$$
\text { Height of the mixture }
$$

\section{RESULT AND DISCUSSION}

The result of the functional properties of flour produced from fermented and unfermented sweet potato and their blends with wheat flour are as shown in the table below.

\section{DISCUSSION}

\section{Functional properties of wheat and sweet potato (fermented and unfermented) flour}

The bulk density value for $100 \%$ wheat flour (WF) was $0.87 \mathrm{~g} / \mathrm{cm}^{3}$ while $100 \%$ unfermented and $100 \%$ fermented sweet potato flour recorded $2.50 \mathrm{~g} / \mathrm{cm}^{3}$ and $2.00 \mathrm{~g} / \mathrm{cm}^{3}$ respectively. The result shows that fermentation decreases bulk density. Diets of lower bulk density is required for infants to allow them swallow it with ease without chocking or suffocation (Ikujenlola et al, 2013). It has been reported that increase in bulk density enhances oil absorption (Narayana and Narasinga 1982). Result from this study are in agreement with this report as $100 \%$ unfermented sweet potato flour with the highest bulk density $\left(2.50 \mathrm{~g} / \mathrm{cm}^{3}\right)$ had the highest oil absorption capacity $220.00 \%$. The oil absorption capacity decreased as more sweet potato flour was added and fermentation also had a reduction effect on the oil absorption capacity. Adeleke and odedeji (2010) reported a similar result on wheat and sweet potato flour blends.

The result of the water absorption capacity as shown in table 1 indicate that fermentation increased water absorption capacity. Beuchat (1976) postulated that breaking peptide bonds of proteins as a result of protcolytic activity during fermentation may cause an increase in polar groups which would increase hydrophilicity of the proteins. The higher water absorption capacity of the fermented flours (100\% FSPF-140.00\% and 90\% WF:10\% FSPF_200.00\%) In this study was probably caused by an increased number of hydrophilic group of the flour protein resulting from fermentation. The foaming capacity followed the same trend as fermentation increased it. Sample that contained fermented sweet potato flour had higher foaming capacities (100\% FSPF - 8.00\% and 90\% WF:10\% FSPF _ 10.00\%) as against the unfermented sweet potato flour with the value of $2.00 \%$.

The results presented in table 1 shows that emulsion capacity of unfermented flour samples are lower than that of the fermented. The emulsion capacity was high in sweet potato flours while the wheat flour had a value of $15.00 \%$. Adeleke and Odedeji (2010) reported a 14.68\% emulsion capacity for wheat flour which is similar to the one obtained in this study. The least gelation of $100 \%$ WF was $18.00 \%$, while the $100 \%$ unfermented and $100 \%$ fermented sweet potato flours had values of $6.00 \%$ and $10.00 \%$ respectively. The least gelation value recorded for sweet potato flour suggests that it may not be good gel for forming agent. This indicates that more flour will be needed to form gel with sweet potato flour because of its low gelation capacity (Adebowale, et al, 2005). However, fermentation improved the gelation capacity as shown in table 2

The swelling index of the flours followed a similar trend with the water absorption capacity. The higher the water absorption capacity, the higher the swelling index in the flours 90\% WF:10\% FSPF with the highest water absorption capacity (200.00\%) had the highest swelling index of 0.88. These two parameter are used in determining the quantity of water that flours can absorb and the degree of swelling with a specified time (Adebowale et al, 2005)

\section{CONCLUSION}

The functional properties of fermented and unfermented sweet potato flour and their blends with wheat flour were investigated. The study showed that fermentation increased most of functional properties evaluated such as foaming capacity $(8.00 \%$ for $100 \%$ FSPF and $10.00 \%$ for 90\%WF : 10\% FSPF),emulsion capacity (25.72\% for $100 \%$ FSPF and $11.72 \%$ for $90 \%$ WF: $10 \%$ FSPF) and least gelation $(10.00 \%$ for $100 \%$ FSPF and $16.00 \%$ for 
018 Afr. J. Food Sci. Technol.

90\%WF: 10\% FSPF).However, fermentation decreased the bulk density from $2.50 \mathrm{~g} / \mathrm{cm}$ in $100 \%$ USPF to $2.00 \%$ in $100 \%$ FSPF. 90\%WF:10\% FSPF with the highest water absorption capacity of $200.00 \%$ has the highest swelling index of 0.88 .

The result from this study showed that blending wheat flour with fermented sweet potato flour improves the function properties.

\section{RECOMMENDATIONS}

Further studies to evaluate the effect of fermentation on the proximate composition, antinutrient properties and mineral composition of flour blends of wheat and sweet potato should be carried out.

\section{REFERENCE}

Adebowale AA, Sanni LO, Awonorin SO(2005) Effect of texture modifier on the physicochemical and Sensory Properties of dried fufu. J. Food Sci. And Technol.;11;373-381.

Adeleke RO, Odedeji JO (2010) functional properties of wheat and sweet potato flour blends.Polastan J. nutri.9(6);535-538.

ALM,1992, Handbook of fermenting functional foods in food chemistry, second edition ,fermentations of flours. ISBN; 2232452526252522.

Austin DF(1988)The taxonomy, evaluation and genetic diversity of sweet potatoes and related wild species in Gregory $\mathrm{P}(\mathrm{ed})$ exploration.

Ballard C, Brown P, Bourko RM, Hardwood T,eds (2005) The sweet potato in Oceania: Reappraisal (Oceania Publications,Sydney).

Bashaasha RO , Mwanga (1992) Sweet potato;A source of income for low-income for low-income rural families in uganda in; Scott G.P Ferguson, and JE herrara.(eds) Product Department for roots and tubers crops vol111 Africa .proceedings of the workshop on processing marketing and utilization of roots and Tubers.

Beuchat LR (1976) fungal fermentation of peanut cake. Journal of Econ.bot.30;227-234.

Camphell - plate 1987; Effects of Fermentation on flour, production, FAO, Plant Production and Protection Paper 130, page $6-35$.

Cariton Leach, March 2007,Determination of swelling Index: 7-7-1959. Functional properties of flours,2334555;673.

Coffman CW, Garcua V V(1977).functional properties and amino acid content of a protein isolate from mung bean flour $J$ food Technology;12;473-480.

Denham T (2011) Early Agriculture and plant domestication in new Guinea and Island Southeast Asia. Curr Anthropol 52;5379-5395.

Dincer C, Karaoglan M, Erden F, Tetik N, Topuz A, Ozdemir $F(2011)$;Effects of baking and Boiling on the Nutrictional and antioxidant properties of sweet potato/Ipomoea batatas(L) Lam\} cultivators plant foods for human Nutriction 66(4).

Egeonu LN(2004), characterization of 35 sweet potato (Ipomoea batata (L)\} assession in southwestern Nigeria. MSc, project ,Department of agronomy, University of Ibadan. Page $24 \mathrm{Vol} 3$

Erickson DL, smith BD, Clarke AC, Sandweiss DH, Tuross N(2005). An Asian Origin for a 10,000 year old domesticated plant in the Americas proc Nah Acad Science USA 102(SI);18315-18320.

Ezeano C(2006),Trends in sweet potato production utilization and marketing among households in southeastern Nigeria PhD Thesis Department of Agricultural extention, university of Nigerian Nsukka Page $31 \mathrm{Vol} 7$

FAO (1989-2001) Nigerian food balance sheet Basic data Branch, statistics Division FAO,viole delle, Termed caro calla 00100,HTTP;http//apps.faoorg.

FAOSTAT (1997) statistics database (online) Assessed, June HTTP;http//apps.faoorg.
Huang JC, M Sun (2000). Genetics diversity and relationships of swee potato and its wild relatives in Ipomoea series Batatas (Convolvulaccaea) as revealed by inter-simple sequence repeat (FSSR) and restriction analysis of chloroplast DNA TAG 100;105001060.

Ikujenlola AV, Oguntuase SO, Omosuli SV(2013), physciochemical properties of complementary food from Malted Quality protein maize(zea mays $L$ ) and defatted pumpkin flour(Telfaira occidentalis Hook F), food and public Health 3(6):323-328.

JA Woolfe (1992) post harvest procedures,"processing ,In sweet potato untapped food source. $43 \mathrm{Vol} 9$

John Williams (1998):Tropical crops:Dicotyledons. An untapped Food Resource .longman scientic and Technical,New York,USA ; John Williams and sons,inc, ISBN 97805824666661.

Ladefoged T N , Grates MW, coil J (2005). The introduction of sweet potato in Polynesia; Early remains in Hawai, $J$ polyn sec $114,359.374$

Low JPK, Gichuki V, Haganimana MA, Oyunuya J, Kabira (1996); combating vitamin A deficiency through the use of beta -carotene rich sweet potato varieties; phase 1 of an action research project in south Nyanza, Kenya, Cip-Nairobi. Page 58 Vol 2

Michelle Schoffro Cook,(1998), PhD, The nutritional compositions of sweet potato flour and the good sources with the nutrients level; The life Force Diet; ISBN 654332776666453.

Narayana AK, Narasinga R (1982)functional properties of raw and heat processed winged bean (Psophocarpus totrsgo nolobug) flour. J. food sci.42;531-538.

Odebode SO (2004). Acceptability of sweet potato, Effective communication teaching methods in technology transfer in Nigeria; Sweet potato processors experience. International Association of Agricultural information Specialists .Quarterly Bulletin pp.96-98.

Ojeniniyi EF, O Tewe(2001), processing and utilization of sweet potato for food and livestock feed in Nigeria, proceedings of the $8^{\text {th }}$ Trennial symposium of the international society for tuber roots crops. Africa Branch (ISTRC-AB), held at Ibadan pp 100.103.

Okaka JC, Peterson NN (1979) Physiochemical and Functional and storage properties of cowpea -wheat flour blends in bread making, J food sci 1977.

Patterson, DR (1998). True, Roots Sweet potatoes, Texas AG Progress, Winter 1979., J-Agric, 2345;56789;7655445.

Roullier C, Bnoit L, Mckey DB, Lebot V (2013) Historical collections reveal patterns of diffusion of sweet potato in oceania Obscured by modern plant movements and recommendation pro $\mathrm{C} \mathrm{NaH} \mathrm{Acad} \mathrm{Sci}$ USA 1102205-2210.

Sathe SK, Salunkhe DK (1981),functional properties of great northern bean(phaseolus Vulgaris) protein; Emulsion, foaming viscosity and gelation properties $\mathrm{J}$ food $\mathrm{sci}, 46-71-75$.

Scott GJ, L Maldonado (1999). Sweet potato facts A Compendium key figures and Analysis for 30 important sweet potato producing countries (CIP), Lima, Peru 142-148.

Tewe, OO, FE Ojeniyi, O A Abu (2003), sweet potato production,utilization and marketing in Nigeria, Social Science Department, International sweet potato centre (CIP),lima, peru, Database (on line). Assessed, march 2003 available june 2005 HTTP; http//www.potato.org/MFESEAP/F/ library/spin Nigeria pdf.

Woolfe , Jennifer A (5 March 1992), sweet potato; An untapped food Resourse,Cambrige ,UK; cambrige University press and the international potato center(CIP);ISBN 9780521402958.

YEN DE (1991). The social impact of sweet potato introduction in Asia and the south pacific;UPWARD sweet potato cultures of Asia and South pacific proceedings of the $2^{\text {nd }}$ annual UPWARD intl. conference UPWARD, los Banos, Phillipines 18-2827.

Zhang DP, J Cervantes, Z Huaman, E Carey, M, (2000). Assessing genetic diversity of sweet potato (Ipomoea batatas (L). genetics Resources and crop evolution 47;659-668 
Key ;

$\mathrm{WF}=$ Wheat flour

USPF $=$ Unfermented sweet potato flour

FSPF $=$ Fermented sweet potato flour

100:0:0 = 100\% WF

$0: 100: 0=100 \%$ USPF

$0: 0: 100=100 \%$ FSPF

90:10:0 = 90\%WF:10\% USPF

90:0:10 = 90\% WF:10\% FSPF 